\title{
LA METÁFORA DE LA VIDA. HERDER, SU FILOSOFÍA DE LA HISTORIA, Y LA HISTORIA DE UN DESENCUENTRO
}

ELfas JosÉ PALTI

UNIVERSIDAD DE CALIFORNIA EN BERKEIEY

CONICET-ARGENTINA

Nadie en el mundo percibe como yo la invalidez de las caracterizaciones generales

Johann Gottfried Herder

Oscurecida por la gloria de sus contemporáneos, la figura de Herder (17441803), según se quejan sus biógrafos, no ha sido aún objeto de la valoración que merece. ${ }^{1}$ Presa por el doble movimiento de ser a la vez elevada a la categoría de símbolo de la emergencia de lo "otro" de la razón, ${ }^{2}$ y reducida al papel de mera disparadora de tendencias que sólo adquieren forma a comienzos del siglo pasado, su obra habría de ser, según suele decirse, más debatida que leída. ${ }^{3}$ Frente a quienes creyeron ver en él el origen de la "era del biologismo", quien instala en el pensamiento occidental una nueva

1 El primero en insistir en esta supuesta injusticia fue Martin Schütze en su Fundamental Ideas of Herder's Thought (publicado en serie en los años 1920 en Modern Philology). El vacío indudable que existe en los estudios sobre Herder, especialmente fuera de Alemania, no ha sido desde entonces realmente llenado, a pesar de la publicación de algunas obras interesantes al respecto. El historicismo y su génesis (1936) de Friedrich Meinecke (Fondo de Cultura Económica, México, 1982) y Herder. His Life and Thought, de R.T. Clark, Jr. (University of Califomia Press, Berkeley, 1955), siguen siendo las más importantes biografías intelectuales de nuestro autor. Una bibliografía específica sobre el tema que nos ocupa se encuentra en H.B. Nisbet, Herder and the Philosophy and History of Science (The Modern Humanities Research Association, Cambridge, 1970). La traducción de todas las citas de libros o artículos publicados en lenguas extranjeras es mía, salvo indicación contraria.

2 A. Gilles abre su, ya clásico, Herder (Basil Blackwell, Oxford, 1945) afirmando que: "Su función me parece la de contraparte de Kant, su gran oponente, en la producción de la mentalidad de Alemania moderna [recuérdese que se trata de un prefacio escrito en junio de 1944]. Él formuló su contenido emocional, mientras que Kant formuló su contenido intelectual" (p. v).

3 El hecho de que la edición de las obras completas de Herder tuviera que esperar hasta 1913 (con la publicación del volumen XXXIII de la editorial Suphan) y que la mayor parte de ella resulte todavía inaccesible salvo en alemán, muestra que el afán por leer sus escritos no ha sido clamoroso. 
"metáfora radical" ${ }^{4}$ en la cual se encontraría ya "prefigura(da) la teoría hitleriana de Blut und Boden", 5 pronto se alzaron quienes insistirían en que "para Herder todos los grupos son colecciones de individuos; su uso de lo 'orgánico' y el 'organismo' es aún puramente metafórico". 6 Entre ambos extremos, se abre un amplio abanico de perspectivas que presentan a este autor como permanentemente desgarrado entre el racionalismo iluminista modernista y el espiritualismo antimodernista romántico (dominando uno $\mathrm{u}$ otro en las distintas fases de su carrera intelectual).

Esta diversidad de puntos de vista oculta, sin embargo, la existencia de cierta premisa compartida (y que hace, en última instancia, posible este debate): la figura de Herder se situaría en el centro mismo de una suerte de falla geológica que por entonces se produce en el transcurso de la historia intelectual europea, ${ }^{7}$ y quie instalaría aquellas alternativas teóricas básicas en torno a las cuales toda ella oscilaría desde entonces. ${ }^{8}$ En su pensamiento, pues, se guardarían algunas de las claves para comprender el sentido de esa ruptura que él inicia, y cuya trascendencia superaría su momento histórico particular. La pregunta por el sentido de los desplazamientos que en esos momentos se producen no parecería, sin embargo, acuciante sino sólo en la medida en que surge la sospecha de que las dicotomías tradicionales (racionalismo vs. espiritualismo, cosmopolitismo vs. nacionalismo, atomismo vs. organicismo, etc.) a las cuales usualmente se apela resultarían por lo menos insuficientes para definirlas; que el significado de categorías tales como las de "organicismo", "evolucionismo", "irracionalismo", "totalidad", etc. -y, por lo tanto, de sus opuestos, "mecanicismo", "racionalismo", "atomismo", etc.-, no es en absoluto transparente, ni su uso ha sido consistente a lo largo del tiempo; que no se tratan de categorías "eternas" (como "tolerancia"

4 Meyer H. Abrams, The Mirror and the Lamp, Oxford, 1953, p. 204; citado por Edgard Schlick, Metaphorical Organicism in Herder's Early Works, Mouton, París, 1971, p. 122.

5 Max Rouché, La philosophie de l'histoire de Herder, Faculté des Lettres de l'Université de Estrasburgo, París, 1940, pp. 25 y 91.

6 Isaiah Berlin, Vico and Herder, Two Studies in the History of Ideas, The Hogarth Press, Londres, 1976, p. 198.

7 El historicismo y su génesis de Meinecke se ha convertido, merecidamente, en el texto clásico por el que se nos retrata la figura de Herder como la de aquel que "descubre la historia"; Auch eine Philosophie der Geschichte zur Bildung der Menschheit (1774) marcaría el hito fundacional del moderno historicismo (Meinecke, El historicismo, p. 308). Para Cassirer, por el contrario, el surgimiento del romanticismo no supuso ninguna ruptura real respecto de la llustración, sino que representó más bien una "autosuperación" de la misma [Cassirer, Filosofía de la ilustración, Fondo de Cultura Económica, México, 1981, p. 260].

8 Su símbolo se encontraría en la controversia surgida entre Herder y su maestro, Kant. La llamada "campaña contra Kant" que Herder desata, se inicia con Metakritik (1799) y Kalligone (1800), obras en las que Herder ensaya una "metacrítica" de la Crítica del juicio de Kant que acababa de aparecer. 
y "autoritarismo") o cuasi eternas (como "democracia" y "dictadura") ni resultan traducibles linealmente en términos tales, sino de construcciones históricas cambiantes y complejas. ${ }^{9}$ Estudios recientes sobre la historia de la ciencia y su impacto en el desarrollo de las filosofías de la historia decimonónica (desgraciadamente, poco conocidos en nuestro medio) ${ }^{10}$ han abonado esa sospecha. En definitiva, lo que muestran es que antes de abrir juicio sobre si Herder sostuvo o no un punto de vista "organicista" de la sociedad y de la historia, es necesario primero intentar discernir qué se entendía entonces por "organismo" o "evolución", cómo el sentido de tales conceptos se va modificando y cuáles fueron los problemas en torno a los que se debatió. Esto es, más específicamente, lo que intentaremos hacer en las páginas que siguen.

\section{El divorcio entre causas y fines}

En El historicismo y su génesis, Meinecke define la filosofía herderiana de la historia como un intento por resolver una tensión heredada del pensamiento ilustrado. En éste, asegura, coexistieron siempre dos tendencias antagónicas, la moralista-finalista y la causal-determinista, sin que se acertara a formular una "teoría general conexa de la causación histórica", ${ }^{11}$ y en ello estribaría la debilidad radical de la conciencia histórica del pensamiento ilustrado. Sin embargo, cabría mejor decir que, lejos de ser tensa, la relación entre causas y fines sencillamente no aparecía como problema dentro del universo de las filosofías Iluministas tardías de la historia (en la idea de la "educación de la humanidad" ambos se conciliaban perfectamente). La obra "juvenil" de Herder (Filosofía de la historia para la educación de

9 Distintos estudios han cuestionado la creencia arraigada acerca del supuesto "espiritualismo anticientificista" del Romanticismo, en general, y de Herder, en particular. Sin embargo, la mayoría de tales estudios se limita a invertir ciertos puntos de vista tradicionales. Así, Herder aparecería ahora como un "positivista temprano" [Martin Schütze, "The Fundamental Ideas in Herder's Thought", Modern Philology, no. 18, 1920-1921, pp. 65-78; citado por Nisbet, Herder and the Philosophy, p. 8]. Y, de este modo, dejan en pie el marco dicotómico de base en el que las aproximaciones tradicionales se sostienen, con lo que pronto tales dicotomías tradicionales vuelven a aparecer. El modelo de racionalidad frente al cual cabría evaluar los logros de Herder se situaría ahora en su horizonte, y ya no a su espalda. El texto clásico que aquí reabre la polémica, y cuyo título es ya suficientemente explícito, es Herder précurseur de Darwin? Histoire d'un mythe de Max Rouché, Faculté des Lettres de l'Université de Estrasburgo, París, 1940.

10 Alexander Göde von Aesch, El romanticismo alemán y las ciencias naturales, Espasa Calpe, Buenos Aires, 1947; Bentley Glass, Owsei Temkin y William Straus, Jr. (comps.), Forerunners of Darwin. 1749-1859, The John Hopkins University Press, Baltimore, 1959; Andrew Cunningham y Nicholas Jardine, Romanticism and the Sciences, Cambridge University Press, Cambridge, 1990.

11 Meinecke, El historicismo y su génesis, p. 127. 
la humanidad, 1774) nos muestra, precisamente, cómo es que tal relación entre causa y fines en la historia se torna problemática.

La pregunta sobre cuál es la finalidad de la historia humana y cuáles los medios por los que ésta se realiza sólo cobraría entidad o densidad propia cuando se pusiera en cuestión la idea iluminista de la existencia de una esencia humana única (el "hombre en general") y una meta común para todo el género humano (la razón). Si bien Herder nunca dudó de la unidad esencial del género humano, entendía sí que el "hombre en general" del iluminismo no era sino una abstracción ("todo concepto general es sólo una abstracción", decía), ${ }^{12}$ resultado de una idealización, una entidad desgajada del tiempo y del espacio ("el prototipo del género humano no se halla, pues, en una nación de la tierra; es el concepto abstraído de todos los ejemplares de la naturaleza humana en ambos hemisferios"). ${ }^{13}$ Pero, entonces, ya no era auténticamente humano, porque el hombre sólo existe en un momento y en un lugar dado, es siempre una criatura determinada, ya inserta en una cultura y época y, por lo tanto, sometido a la contingencia y al cambio. Y esto plantea un primer problema relativo a la inteligibilidad de los fines que orientan el desarrollo histórico de la especie dado que, junto con la idea del "hombre en general" se quebrarían también los parámetros absolutos (transculturales) respecto a los cuales se confrontan los progresos alcanzados, a través de las diversas épocas, por las diferentes naciones. Todo juicio histórico supone valores que son, inevitablemente, culturalmente determinados, y, por lo tanto, contingentes ("toda perfección humana", decía, "es nacional, secular y, estrictamente considerada, individual") (p. 55). De allí que lo verdaderamente sustantivo en la historia no sea el "hombre en general", ni tampoco los individuos históricos, sino los "espíritus de los pueblos" (Volksgeistes) dentro de los cuales éstos se definen y forman. Cada "espíritu del pueblo" conforma una totalidad de sentido que, como las mónadas de Leibniz, constituye un universo cerrado que realiza por sí solo el ciclo biológico completo de crecimiento, decadencia y muerte. Desaparecida, pues, toda instancia unitaria esencial, como la que suponía el "hombre en general", parece que sólo nos quedara la caótica e infinita variedad de sus manifestaciones empíricas particulares. Entonces sí la pregunta por el sentido de la historia, como tal, se tornaría insoslayable.

Si yo lograra unir las escenas más dispares sin entremezclarlas, si lograra demostrar en qué forma se relacionan, cómo se desprenden unas de otras, cómo

12 Herder, Filosofía de la historia para la educación de la humanidad, Nova, Buenos Aires, 1950, p. 54. En adelante: la paginación que aparece en el texto corresponde a esta obra.

13 Herder, La idea de humanidad, Instituto de Literatura Alemana, Facultad de Filosofía y Letras-UBA, Buenos Aires, 1954, p. 67. 
se pierden, se confunden entre sí, cómo cada una es un momento y sólo por su encadenamiento es medio para fines, iqué espectáculo! iqué noble aplicación a la historia humana! iqué estímulo para tener esperanzas para obrar, para crecer incluso allí donde o no se ve nada o no se ve todo! ${ }^{14}$

Sin embargo, encontrar una respuesta a tal dilema resultaba particularmente problemático debido a que la misma involucraba cuestiones no ya exclusivamente de índole gnoseológica. Con la quiebra de la idea del "hombre en general" surgía no sólo el problema de cómo conocer cuáles son los fines a los que la especie se orienta, sino algo aún más fundamental: cómo estos fines actúan en la realidad, cómo se desenvuelven y realizan a través de las distintas épocas y culturas. En el concepto de Herder, la historia misma tendía (casi inevitablemente) a tornarse circular puesto que no habría forma de atar los distintos principios particulares entre sí. En efecto, agotadas sus fuerzas vitales, cada época y cada cultura volverían siempre, para Herder, a recaer en la barbarie (al estado de puro conflicto primitivo), y a ninguna de las fuerzas históricas actuantes (todas ineludiblemente relativas a la propia cultura en decadencia) les estaría ya dado poder superar por sí mismas (como tampoco podía el Barón Munchhäusen salir del barril en que estaba atrapado tirándose a sí mismo de los pelos) el sino trágico que las enfrenta. Condenadas así a perecer junto con la época y la cultura que las habían engendrado, no parece existir instancia de continuidad posible entre ellas (ningún punto arquimédico colocado por encima o por fuera de las mismas).

Aún entonces, sin embargo, Herder nunca cuestionaría la idea de que existirían fines universales inherentes al hombre como tal. Muchos olvidan que la "felicidad" relativa a cada cultura a que se refiere Herder en su famosa máxima ("cada nación lleva en sí el centro de su felicidad, así como cada esfera lleva en sí su centro de gravedad") (p. 58), se trata de una "felicidad sensible" a la que él opone una "felicidad absoluta" común para el género humano y que se va desenvolviendo en el tiempo de forma continua $y$ progresiva.

El refinamiento y el progreso purificador de los conceptos de virtud desde las épocas más materiales de la infancia a través de toda la historia es evidente; la difusión y el vasto progreso son evidentes. $Y$ todo esto, ino tendrá alguna finalidad, alguna intención? Se sabe que los conceptos de libertad humana, sociabilidad, igualdad y felicidad absoluta se van aclarando y difundiendo (p. 133).

14 Ibid., pp. 62-63. 
De todos moû̉os, llegado a este punto, no habría ya, según parece, vínculo alguno concebible que uniese los fines particulares de cada pueblo (la "felicidad relativa") con los universales en la historia (la "felicidad absoluta"). Aunque quizás para algunos resulte paradójico, el hecho es que fueron las mismas ciencias naturales de la época, a las que Herder supuestamente rechazaba, ${ }^{15}$ las que le ofrecerían el modelo con que no sólo produce la quiebra del concepto iluminista del "hombre en general" sino que también intenta empezar a pensar, sobre una nueva base, la idea de la estructura del plan divino de la creación en su conjunto (incluida la necesidad de sus misterios), y, en particular, de cómo se articularían en él estos dos sistemas de finalidades (particulares y universales) en apariencia contradictorios entre sí (idea confusa, por otra parte, y sobre la que se sostienen aquellas interpretaciones que encuentran la obra de Herder sujeta a tensión por la coexistencia de dos sistemas de pensamiento en conflicto).

\section{Evolucionismo y transformismo en la llustración tardía}

En The Shape of Romanticism, Marshall Brown insiste en la importancia de la "forma" en el pensamiento romántico. Esta idea de "forma" nos brinda una clave para comprender mejor la filosofía de la historia de Herder y su conexión con las ciencias naturales de su tiempo. Para Herder, así como para sus seguidores, "la línea de la perfección era el círculo, donde todo brilla desde un centro y vuelve al mismo". ${ }^{16}$ Lo que es perfecto es autocontenido, encierra dentro de sí su propia idea. El concepto herderiano de Volksgeist expresa, precisamente, tal ideal de perfección. Él es un organismo que se autoengendra y autorregula, él contiene dentro de sí su propia finalidad inmanente. Sin embargo, para Herder al hombre no le es dada tal perfección. Tampoco a su mundo, recluido como está, desde Copérnico en adelante, en un oscuro rincón del universo. La armonía de fuerzas que existe en él es únicamente contingente, su circularidad es sólo tal, vista desde su interior, pero nunca en un sentido absoluto. Kepler había utilizado ya el argumento de la imperfección del universo creado para fundamentar su hipótesis de la órbita elíptica de los planetas. Pero la elipse expresa una simple imperfección sin conexión alguna con lo absoluto. Hacia fines del siglo xvin, sin embargo, la imagen del orden del universo se había tornado más compleja

$15 \mathrm{Y}$, en efecto llamaba a que "en vez de reducir la gran creación de Dios a la dimensión de una pequeña construcción surgida de tu cabeza (de cosmogonía, génesis animal, geometría, etc.), sólo aspira a seguir la corriente de la fuerza divina, a sentirla y trata de hacerla sentir profunda y fielmente en todas sus formas, figuras y producciones, para servirle al Creador y no a ti" (Filosofia de la historia, p. 126).

16 Herder, "Plastik", en Werke VIII, no. 64; citado por Brown, The Shape of Romanticism, Cornell University Press, Ithaca y Londres, 1979, p. 28. 
y ofrecía ya a Herder el modelo con el cual pensar cómo el sistema de las finalidades relativas podía conectarse con un centro absoluto sin volverse por ello reductible a éste ni emanar linealmente del mismo.

_Así como el mundo gira en torno al Sol, se pensaba ya entonces que éste, a su vez, giraba en torno a un centro galáctico, y así sucesivamente. El verdadero curso de los cuerpos celestes sería, pues, según este concepto, la cicloidea (cuya forma precisa sería siempre específica a cada uno de ellos) resultante de la superposición (particular) de infinitas trayectorias orbitales. ${ }^{17}$ Pero esto significaba que debía existir un centro absoluto del universo en torno al cual los planetas y estrellas rotasen y que explicaría la regularidad de sus desplazamientos. Como decía Kant (quien estaba trabajando en su cosmología en tiempos en que Herder era discípulo suyo):

Una constitución del mundo que no se mantiene sin un milagro, no tiene el carácter estable que es la marca de la elección de Dios [.. . ] Un puñado esparcido de sistemas, dado que deben estar separados entre sí, entraría, por una tendencia incontrolada, en un proceso de desorden y destrucción, a menos que se hiciera cierta disposición relativa por referencia a un centro universal, el centro de atracción del universo. ${ }^{18}$

Las cosmologías de la Ilustración tardía se orientarían así a intentar descubrir este orden oculto del $\operatorname{cosmos}^{19}$ y, de este modo, completar la revolución astronómica iniciada por Copérnico. La misma suponía, fundamentalmente, una crítica de las apariencias: el orden del universo que se extiende desde un centro situado más allá de nuestros sentidos, no nos estaría inmediatamente dado debido a nuestra excéntrica posición dentro del mismo. Pero este desplazamiento del hombre del centro cósmico se vería compensado por el don de la ubicuidad (la capacidad de colocarse al mismo tiempo en distintos puntos de vista) que éste, en tanto ser racional, hereda del Dios tardío-medieval. Kepler es el primero que ensaya una perspectiva de cómo se vería el cielo desde la Luna. Lambert (a cuyas Cartas Cosmoló-

17 "Podemos percibir claramente", decía Johann Friedrich Lambert, "que la elipse no es la única especie de movimiento que obtenemos en el mundo. Nuestra teoría requiere, sin embargo, que el movimiento se torne más complicado en la misma proporción en que ellos se alejan del centro universal" [Lambert, "Cosmological Letters", en M. Munitz, Theories of the Universe, The Free Press, Nueva York, 1957, p. 258].

18 E. Kant, "Universal Natural History and Theory of the Heavens", en Munitz, Theories of the Universe, p. 241.

19 Quien propone este proyecto es Thomas Wright, quien, en su An Original Theory or New Hypothesis of the Universe (1750) afirmaba que "es a este gran orden que me dedicaré, y así a resolver el fenómeno de la Vía Láctea" (en Munitz, Theories of the Universe, p. 228). 
gicas Herder luego llamaria "una gloria del género humano") ${ }^{20}$ desarrolla sistemáticamente este modelo de combinar diversos puntos de observación a fin de descubrir el orden oculto del universo y acceder, finalmente, a una visión del centro de atracción universal desde donde todas sus partes perderían su apariencia caótica y revelarían su íntima armonía.

La cicloidea, en fin, es también la "forma" del pensamiento histórico de Herder hacia 1774. La historia de cada individuo en particular surge, pues, y sólo puede entenderse como resultando de la superposición de órbitas en torno a distintos centros relativos, los cuales, a la vez, gravitan todos alrededor de un centro incondicionado hacia el que tienden. Como vemos, no existe tensión alguna en tal superposición de sistemas de finalidades. Las cosmologías ilustradas proveían la forma de base para concebir un modelo en que las mismas podían articularse entre sí formando un sistema único sin perder por ello su particularidad (su propio centro). Sin embargo, la extrapolación de este modelo a la historia y puesto que entramos en el terreno del reino de los fines y valores, abre una nueva serie de interrogantes. Los mismos derivan básicamente del hecho de que el centro absoluto del que aquí se trata ya no sería un centro meramente topológico, sino ideal. $Y$ ello torna complicada su definición en términos seculares ("idónde está", preguntaba, "el gran círculo de todas esas ondas, rayos y centros aparentes?, ¿dónde está, qué es, para qué está?") (p. 115) y, en particular, la explicación de cómo ejerce éste su acción por medio de agentes puramente físicos.

Resuelta la tensión entre fines particulares y universales, surge ahora la (supuestamente) más antigua entre causas y fines. Pero dicho problema, tal como aparece en Herder, no es ya verdaderamente una herencia de la Ilustración, sino que sólo se plantea en la medida en que esa idealización del centro de que hablamos resulta en él correlativa (al menos, en el plano histórico-moral) a una quiebra de la idea del don de la "ubicuidad" de la razón: siendo que nuestra cultura condiciona nuestros puntos de vista desde dentro, no existiría para el hombre perspectiva posible por fuera de la de su propio tiempo y lugar (no habría forma de "componer" las distintas vistas posibles de la historia en una sola imagen). Y, nuevamente, no se trata aquí sólo de una cuestión gnoseológica, sino que involucra problemas de índole fundamentalmente ontológica. Éstos se relacionan con las características y naturaleza de la fuerza que operaría en la historia.

Este problema que aquí surge es particularmente grave porque toca el núcleo de la filosofía de la historia de Herder. El verdadero sentido de la "ruptura epistemológica" que efectivamente inicia Herder no podrá hallarse tanto por el lado de una supuesta negación de toda idea de "naturaleza" o

20 Citado por Blumenberg, The Genesis, p. 539 (no se consigna la fuente, pero se trata de Adrastea). 
"esencia" humana (como algunos de sus críticos creen ver al menos esbozado en su doctrina), sino qué es lo que él identifica como tal. En efecto, la "filosofía de la historia" de Herder ya no preguntará por el "hombre", sino por la "Humanidad"; 21 y esto supondría un giro fundamental respecto de las filosofías de la historia de la Ilustración tardía. De este modo, Herder no anula la idea de una instancia universal común a todo el género humano (puesto que de lo contrario parecía inevitable una recaída en el relativismo absoluto), pero ésta ya no se tratará de ningún ser, rígido e inmutable, ninguna supuesta serie de rasgos definidos que identifican al hombre a través de los tiempos y lugares (y que "Adán pudo también conocer", según decía Malebranche). Lo que define a la especie se encuentra más allá de lo dado inmediatamente a los sentidos: son las capacidades invisibles (Kräfte) para producir tales rasgos visibles así como la tendencia (Bildungstrieb) a hacerlo (los "trascendentales objetivos" de que habla Foucault en Las palabras y las cosas). Y esto produce un desplazamiento decisivo en los modos de interrogarse sobre el mundo (deslizamiento que se denuncia en su lectura de Lambert, a cuya cosmología consideraba sólo un paso preliminar en la comprensión "de la aurora de la Creación"): ${ }^{22}$ a diferencia de Lambert, Herder ya no se preguntaría por la estructura de su universo, sino por cómo ha devenido tal (problema que en el plano físico no se plantearía; de allí que Herder insistiera en la idea de una asimetría entre los procesos sociales y naturales, dado que sólo respecto de los primeros puede hablarse de una constitución progresiva: "sólo el hombre", decía, "se encuentra en contradicción consigo mismo"). ${ }^{23}$ Ya en su Ensayo de una historia de la poesía lírica, una de sus primeras obras, Herder explicaba así lo que llamaba su método genético:

No sólo es placentero sino también necesario buscar el origen de la materia a la cual uno busca entender con cierta completitud. Faltando el origen, perdemos obviamente una parte de su historia, y cuán importante es la historia para la explicación del todo. Especialmente la parte más importante de donde todo deriva; porque, como el Árbol deriva de sus raíces, el progreso y florecimiento de un arte debe ser derivable de su fuente. Así como la semilla contiene, escondida dentro, la planta entera con todas sus partes, la fuente de una arte contiene

21 "La verdadera filosofia humana", decía, "consiste en descubrir las huellas de esta Humanidad" (La idea de humanidad, p. 9).

22 Citado por Blumenberg, The Genesis, p. 539.

23 El carácter contradictorio del hombre, afirmaba que es "el sello de Dios en nuestra naturaleza; el árbol que transforma el Conocimiento del Bien y el Mal en el eterno Árbol de la Vida" (Sämtliche Werke IX, no. 540; citado por Clark, Herder. His Life and His Thought, p. 246). 
dentro de sí la entera naturaleza de su producto; y me será imposible derivar de la forma subsecuente el grado de ilustración que hace mi explicación genética. ${ }^{24}$

Es entonces que Herder introduce aquel concepto para designar las fuerzas formativas que dan origen a cada nueva y determinada forma de vida: Kraft, la cual ya no sería, estrictamente considerada, un poder puramente material. Como decía respecto del lenguaje en su primera parte de $E l$ documento más antiguo de la humanidad (1773):

Debe ser, por lo tanto, una fuerza (Kraft) exterior la que despierte esta conciencia [la capacidad del lenguaje], la cual no es nada sino una capacidad, i.e. receptividad; de lo contrario hubiera permanecido por siempre dormida, en la oscuridad, muerta. ${ }^{25}$

Su aplicación de este concepto ( $K r a f t$ ) al plano histórico resultaría, sin embargo, inconsistente, al encerrar una ambigüedad radical: fácilmente se deslizaría para referir también a aquellos principios específicos (Kräfte, en plural) que definen a un pueblo en particular, o Volksgeist (Herder incluso traduce, y elogia, la teoría de las mónadas de Leibniz como teoría de las Kräfte). La idea de Herder es que no se trataría aquí de un único impulso universal, sino de agentes específicos a cada formación particular que ejercen su influjo sólo desde el interior de la misma. Si bien la "Humanidad" como tal constituye una única sustancia, ésta para Herder, sin embargo, estaría compuesta de una pluralidad de principios diversos, los cuales no serían nunca reductibles entre sí. Como vimos, cada "espíritu del pueblo" representaría, para él, "un estado único del mundo que no puede ser comparado con ninguno anterior" (p. 75) (i.e., "sustancias" en el sentido de Leibniz). Sólo éstos se nos aparecen empíricamente y constituyen, pues, el objeto legítimo de la consideración histórico-genética. ${ }^{26} \mathrm{Y}$ ello es así porque, entendido como fuerza formadora, el germen sólo puede contener un único principio de desarrollo que le es específico a su naturaleza particular. Pero, al mismo tiempo, cada uno de estos principios remitiría también a aquél misterioso centro absoluto (y único) (Kraft) en torno al cual giran todos los demás y hacia el cual tienden (la Humanität). Y aquí el concepto lambertiano encontraba su límite. Trasladada al plano de la historia, la cicloidea como analogía no alcanzaba aún a explicar cómo actuaba ese "centro universal": concebido éste como una fuerza esencialmente dinámica, no

24 Herder, Sämtliche Werke, Suphan, Berlín, 1877, vol. XXXII, pp. 86-87.

25 Ibid., vol. VI, pp. 299 y ss.; citado por Clark, Herder. His Life and His Thought, p. 169.

26 "Cuando Averroes", decía Herder, "creía que todo el género humano tiene una sola alma, en la que los individuos participan, ya activa, ya pasivamente, aplicaría yo esta concepción poética más bien al espíritu de los tiempos" [Herder, La idea de humanidad, p. 75]. 
era posible aún imaginar cómo ese centro universal, siendo único, podía, sin embargo, contener en él principios radicalmente diversos entre sí. De hecho, Herder no creía que pudiera concebirse a la humanidad toda como resultado del despliegue de un único germen, puesto que esto significaría establecer una suerte de deducibilidad entre los diversos principios que la constituyen (en tanto que cada uno de ellos se encontraría ya contenido en el anterior), es decir, una vuelta al monismo spinoziano. El concepto que está actuando aquí tiene un origen distinto del visto hasta ahora (las astronomías de la Ilustración tardía), aunque igualmente impregnado de las doctrinas científico-naturales de la segunda mitad del siglo xviI; en este caso, las biológicas. Para entender el tipo de dilemas que a Herder se le planteaban entonces es necesario considerar cuáles eran las ideas de "evolución" y "generación" que se encontraban operando en él.

Cada una de éstos términos ("evolución" y "generación") remitía, para Herder, a instancias diversas del devenir histórico, instancias cuya distinción se fundaba, a su vez, en un concepto originalmente desarrollado en el ámbito de la llamada "historia natural". Como hemos visto, el concepto de Volksgeist que Herder elabora está tomado del modelo de la mónada leibniciana. ${ }^{27}$ La concepción de un sistema autorregulado y autocontenido tal surge, a su vez, de la teoría formulada primero por Marcello Malpighi (1628-1694) y que luego se conocería como del preformismo biológico. ${ }^{28}$ Según ésta, si aislamos la hipótesis de una intervención sobrenatural continuada en el desarrollo de todo organismo, debemos suponer que todos sus estados posteriores se contendrían ya, al menos como una posibilidad potencial de desarrollo, en su germen. El descubrimiento, por Jan Jakob Swammerdam (1637-1680), de la perfecta preformación de la mariposa en la crisálida parecía confirmar tal hipótesis. ${ }^{29} \mathrm{Y}$ ello consolida una visión

27 "Los cambios naturales de las mónadas", decía Leibniz, "vienen de un principio interior, puesto que una causa exterior no puede influir en su interior" ["Monadologfa"; en Monadología. Discurso de metafísica. Profesión de fe del filósofo, Hyspamérica, Buenos Aires, 1983, no. 11, p. 24] para concluir de ello que "el alma tiene en sí el principio de todas sus acciones y todas sus pasiones" [Teodicea, Claridad, Buenos Aires, 1946, no. 65, p. 146].

28 En varios textos Leibniz hace explícita esta relación. "La preformación de las plantas y de los animales", dice, "es una verdadera prueba que confirma mi sistema de la armonía preestablecida entre el alma y el cuerpo, en la que éste es arrastrado por su constitución original a ejecutar, con el auxilio de las cosas externas, todo lo que hace siguiendo la voluntad del alma; de la misma manera en que los gérmenes, por su constitución originaria, ejecutan naturalmente las intenciones de Dios" (Teodicea, p. 40).

29 Desde entonces, la discusión va a girar fundamentalmente en torno de si tales gérmenes se encontraban en los ovarios femeninos (tesis defendida por Valisnieri y los partidarios del "ovismo"), o bien en los espermatozoos masculinos (según sostenía la llamada escuela de los "animalculistas") descubiertos por Leeuwenhoeck mediante la utilización de microscopios que él mismo perfeccionó. 
fijista de la naturaleza, precondición, a su vez, para el proyecto taxonómico de Linneo. Leibniz provee el sustrato filosófico para tal empresa. Éste retoma la distinción escolástica entre fulguratio y evolutio para diferenciar entre la génesis (que sólo puede emanar de Dios, puesto que ninguna sustancia puede ser, sin contradicción, atributo de otra sustancia) ${ }^{30}$ de una nueva forma de vida, por un lado, y su desarrollo posterior, por otro. Como vemos, el significado del término "evolución" era exactamente el opuesto al que sólo muy posteriormente adquiriría, y sólo así permitía a Leibniz reducir la intervención divina al momento único de la Creación.

El concepto de preformación germinal explica dos aspectos fundamentales de la filosofía herderiana temprana de la historia: cuál es el modelo que está funcionando por detrás de su concepto de Volksgeist, pero también, fundamentalmente, por qué no era posible para él pensar, dentro de este contexto teórico, la idea de una articulación entre las distintas épocas históricas. Como muestra Arthur Lovejoy, aun cuando Leibniz, en su Protogea (1693), esbozara (según interpreta Lovejoy) una hipótesis transformista, ésta conducía a contradicciones insolubles dentro de su sistema, dado que la temporalización de la "escala del ser" cuestionaba los dos principios fundamentales sobre los que la idea de la misma se sostenía: los de continuidad y razón suficiente. ${ }^{31}$ Y ello no sólo porque, como afirma Lovejoy, la sola idea de una mutación en las especies vivas presuponía la existencia de "agujeros" en el orden de la creación, que se llenarían sólo progresivamente lo que tales principios justamente negaban, sino porque desmoronaría el objeto mismo en torno a los cuales tales principios se ordenaban: si un determinado ser contuviera germinalmente capacidades infinitamente plásticas de desarrollo, la explicación de su confluencia hacia aquellas formas específicas de vida que definen a su especie particular conllevaría la reintroducción de la hipótesis de una guía y tutela providencial permanente sobre el mundo. ${ }^{32}$

El primero de los problemas (el señalado por Lovejoy) pronto dejaría de serlo: luego del terremoto de Lisboa de 1755 (visto desde la perspectiva que

30 "A la producción de modificaciones jamás se ha llamado creación, y esto no es más que confundir los términos para asustar a la gente. Dios produce sustancias de la nada, y las sustancias producen accidentes por virtud de los cambios de sus mismas limitaciones" (Teodicea, no. 368, p. 395).

31 Arthur Lovejoy, The Great Chain of Being. A Study of the History of an Idea (1936), Harvard University Press, Cambridge, Mass., 1964, cap. IX: "The Temporalizing of the Chain of Being", pp. 242-287.

$32 \mathrm{El}$ ataque a la idea de que Dios deba intervenir permanentemente en el mundo fue el centro de su disputa con Clarke y, a través de él, con Newton [H.G. Alexander (comp.), The Leibniz-Clarke Correspondence, Manchester University Press, Nueva York, 1956; véase también el análisis del mismo en A. Koyré, Del mundo cerrado al universo infinito, Siglo XXI, México, 1985]. 
difunde Voltaire), tal idea de la perfección del orden físico de la creación sería puesta en cuestión. Al mismo tiempo, el descubrimiento de fósiles de especies extintas llevaría incluso al paladín del preformismo, Charles Bonnet (1720-1793), entre otros, a postular la idea de "eras geológicas", divididas entre sí por cataclismos (de allí que tomaran el nombre de hipótesis "catastrofistas") y cada una con su fauna específica. Pero el segundo de los interrogantes se mantendría todavía en pie: cómo surgen o resurgen las especies luego de cada cataclismo seguiría siendo un misterio, que incluso se agudizaría. La sistemática reproducción del mundo de las especies vivientes tras cada uno de los cataclismos parecía ya tornar completamente insuficientes las explicaciones mecanicistas-epigenetistas a la La Sage (quien en El Lucrecio newtoniano (1748) imaginaba el Génesis como resultando de un deslizamiento puramente casual de átomos). Las doctrinas preformistas se defenderían mejor, pero sólo bajo el supuesto de que tras cada catástrofe aún subsistirían intactos los gérmenes de la preformación orgánica. Las respuestas usuales, sin embargo, remitirían ahora a una combinación de la acción de fuerzas naturales (gérmenes subsistentes) y sobrenaturales (efluvios activadores de la vida latente). Vemos, pues, cómo, así como el epigenetismo presuponía un elemento de preformación, la temporalización de la cadena de los seres reintroduciría, a su vez, un componente vitalista ${ }^{33}$ en las doctrinas preformistas. Si el preformismo fijista fue la precondición para la fijación taxonómica del mundo de las especies vivas, el catastrofismo vitalista sería la primera forma de pensar su historicidad. ${ }^{34}$

La originalidad de la filosofía temprana de Herder consiste, precisamente, en aplicar este concepto a la historia, combinando así un preformismo intra con un vitalismo inter espíritu de los pueblos. En efecto, a la idea (de matriz preformista) de Volksgeist Herder le superpondría un concepto vitalista (de connotaciones claramente teológicas) que le permitiría dar cuenta de eso que hasta aquí parecía un misterio: cómo es que la historia humana se anuda conformando una totalidad de sentido. La combinación de ambos resulta en un catastrofismo cuya resolución remite necesariamente a una instancia trascendental: sólo una intervención providencial podría enlazar,

33 Esta idea remite a W. Harvey (1578-1657) quien sostuvo que el polluelo se desarrolla del huevo sólo progresivamente. El huevo posee no sólo la masa, sino también el principio vital que determina la estructura especial del futuro animal. Las hembras poseerían en su interior algo así como las ideas de los seres. Pero su fecundación requería la acción del semen masculino que proveería aquella fuerza activa que las anima, así como el imán presta su fuerza magnética al hierro. Esta analogía del modo de operar de los principios vitales se tornaría, como veremos luego, muy popular a fines del siglo xvil por obra de Mesmer y Galvani.

34 La alianza entre "catastrofismo" y teísmo, debido al concepto finalista implícito en aquél, fue particularmente estrecha en Inglaterra y hecha explícita por James Huttón en su Theory of the Earth (1788). 
en los momentos críticos, el curso histórico en una unidad de sentido. De alli que las filosofías de corte naturalista, piensa, sí puedan dar cuenta de cómo se produjo la formación de los elementos de que se vale una cultura, de las modificaciones que sufrieron sus diversos componentes producto de la acción del medio y los agentes naturales. Pero, según éstas, su confluencia en un momento dado aparece siempre como un mero concurso casual, no existe ninguna finalidad perceptible en ello. El determinismo causalista encuentra su contrapartida en la aleatoriedad finalista, es decir, conduce inevitablemente a un relativismo absoluto. ${ }^{35} \mathrm{Y}$ ello ocurre porque las explicaciones naturalistas no tenían para Herder nada que decirnos respecto a cuál es el sentido histórico de una cultura como entidad espiritual. La emergencia de un nuevo principio vital (Kraft), ese "elemento activo que liga todos [aquellos elementos] y los transforma en criatura viviente de Dios" (p. 75), nunca es un mero resultado o continuación de las condiciones preexistentes ("el curso de la Providencia llega a su destino pasando por millones de cadáveres") (p. 134). Tampoco ningún agrupamiento o reorganización de la materia puede explicar las transformaciones de las fuerzas espirituales internas que viven en ella. Éstas sólo pueden emanar, pues, directamente de una fuente sobrenatural. Su origen, en fin, supone una suerte de nueva alianza.

Según lo que se ha visto hasta aquí, la solución herderiana temprana a la pregunta surgida sobre la finalidad de la historia parece que consistiera en un simple desplazamiento de la problemática histórica antes que en una redefinición radical de la misma. Sencillamente, Herder habría trasladado a un plano suprasensible aquella instancia unitaria y universal (la esencia inmutable de la naturaleza humana) para poder así abrirse libremente a la infinita variedad de sus manifestaciones seculares sin por ello perder el vínculo de inteligibilidad que las liga a todas ellas en una unidad de sentido. El famoso "relativismo" herderiano quedaría relegado así al plano positivo de la historia; considerada como "entidad espiritual", reinaría en ella la más absoluta linealidad. ${ }^{36}$ Aquí Herder no sólo parece traicionar su alegado historicismo, sino incluso volver a un concepto de la historia

35 "Otros que percibieron la fragilidad de esta ilusión [creerse el centro hacia el cual todo converge]", decía, "no llegaron a una conclusión mejor. Reconocieron que los vicios y las virtudes varían con los climas, que las perfecciones surgen y sucumben como la primavera; que las costumbres y los sentimientos humanos vuelan y revolotean como hojas del destino; isin plan, sin progreso, eterna revolución - tejer y destejer- trabajo de Penélope! Cayeron en un remolino, en un escepticismo con respecto a toda virtud, felicidad y destino del hombre" (Filosofía de la historia, p. 61).

36 "Todos los fines exclusivamente físicos y políticos se desmoronan hechos trizas y como cadáver; el alma, el espíritu, continuado por la totalidad de la Humanidad, permanecen" ( $L a$ filosofía de la historia, pp. 39-40). 
llanamente "reaccionario", es decir, reintroduce en la historia precisamente aquello que las doctrinas preformistas trataron de excluir de la misma y recluir en el momento único de la Creación. Y, sin embargo, en este costado "reaccionario" (o, mejor dicho, en la combinación de este "vitalismo" en el nivel del género humano con un "preformismo" en el nivel de los "espíritus de los pueblos") se encuentra, precisamente, el cambio más decisivo que él produce, el inicio de una auténtica revolución epistemológica: aun cuando mantenga la idea de la unidad del plan divino de la creación, éste habría ya de desplegarse temporalmente; su realización no remitiría ya a un único acto primero, sino que conllevaría una serie de etapas sucesivas (resultado de "fulguraciones" producidas históricamente). También en el plano moral (como en el físico-natural) el catastrofismo vitalista sería, pues, la primera forma de pensar su radical historicidad. Con éste se introduce en él una primera versión de lo que hoy se llama la "flecha del tiempo". El tiempo pasa a ser una dimensión constitutiva del orden del mundo moral; éste no habría sido fijado de una vez y para siempre, sino que sólo se iría conformando (y no sólo "desplegando") históricamente. Los procesos históricos adquieren entonces un carácter irreversible ("en ningún país la cultura ha podido retroceder", afirmaba, "no ha podido ser lo que había sido la primera. La ruta del destino es rígida como el hierro [...] ¿acaso el día de hoy puede llegar a ser el de ayer?"). ${ }^{37}$

Sin embargo, como dijimos, este concepto resultaba aún problemático; y ello es así porque, al mismo tiempo que con esta búsqueda de los "orígenes" apuntaba más allá del horizonte de problemas de la Ilustración, el mismo se encontraba cruzado todavía por las oposiciones entre las ideas de fulguratio y evolutio heredadas de la "historia natural" de aquélla. También en Herder existe aún una correlación entre un completo indeterminismo en los orígenes de un nuevo ser (sea éste un hecho natural -el deslizamiento de átomos-, o sobrenatural — la Creación-) y un determinismo absoluto en su desarrollo posterior. ${ }^{38} \mathrm{La}$ introducción de la idea de una intervención providencial en una matriz preformista de pensamiento es lo que le permite romper con las limitaciones del concepto histórico de la Ilustración, pero de ningún modo alcanza aún a resolver el tipo de problemas que a partir de entonces se plantean: está claro que la apelación a Dios era sólo un asylum ïnorantiæ. Y su mero trastocamiento en el concepto de Kraft tampoco aportaba por sí mismo ninguna solución; éste sería todavía para Herder

37 Herder, La idea de humanidad, p. 121.

38 También en la física newtoniana al absoluto determinismo de la dinámica de un sistema clásico de partículas se le opone el completo indeterminismo de sus condiciones iniciales: conocidas éstas, se puede predecir perfectamente la trayectoria posterior de los cuerpos del sistema en cada instante, pero tales condiciones iniciales deben ser dadas. 
más bien el nombre puesto a un problema que aún habría que desenvolver. La gran cuestión pendiente, y en torno a la que se debatirá no sólo toda la obra posterior de Herder, sino también todo el pensamiento europeo en la primeras décadas del siglo pasado, sería la de cómo introducir un elemento dinámico dentro de la matriz de pensamiento preformista (la cual, en principio, resultaba contradictoria con cualquier idea de transformación) sin necesidad de apelar a la acción de fuerzas misteriosas o sobrenaturales.

\section{La traducción fisicalista de las Qualitates Occultæ}

Considerando lo expuesto, no es sorprendente que los escritos de 17731774, y especialmente el documento más antiguo, tuvieran una unánime mala acogida. ${ }^{39}$ Estos escritos provócaron, por otra parte, la ruptura de Herder con Goethe, quien, en 1774, escribió Satyros haciendo mofa de su concepto de Kraft. Con dicho concepto, Herder parecía haber quedado atrapado en el ámbito de los paralogismos de la razón de que hablaba Kant. En realidad, Herder toma la idea de Kraft precisamente de Kant; pero él la reformula y la liga a una intuición básica, común al pensamiento de la época, de que todo en la naturaleza se encuentra comunicado. Dicha intuición, que tuvo siempre connotaciones místicas, comenzaría, sin embàrgo, hacia fines del siglo xviI, a ganar credibilidad empírica. Maupertuis había ya intentado, hacia mediados de siglo, reducir el carácter misterioso de fuerzas tales como la gravedad, asociándolas a aversiones y repulsiones naturales inherentes en las mismas partículas físicas (idea presente en Swedenborg y retomada luego por Goethe en sus Afinidades electivas, aunque ya entonces reformulada, bajo la inspiración de Lavoisier, en términos de "afinidad química"). De todos modos, el carácter enigmático de las mismas no parecía, en sí mismo, particularmente irritante. ${ }^{40} \mathrm{El}$ aspecto preocupante para sus contemporáneos (tanto teístas como racionalistas) del concepto herderiano de tales fluidos comunicantes, y que demandaba una explicación, radicaba en el hecho de que en él (como también en Blumenbach, y luego, en Lamarck) adquiriesen un carácter esencialmente activo cuya naturaleza específica, Herder mismo lo reconocía, no acertaba, sin embargo, aún a definir. "No digo que explique nada por él mismo", afirma, "no conozco filosofía alguna

39 Frente al ataque de los racionalistas, Hamman se vio obligado a defender a Herder, pero en una carta dirigida a él confesaba que tal obra le había parecido un "monstrum horrendum" (citado por Clark, Herder. His Life and His Thought, p. 170).

40 En su Venus física (1749) el mismo Maupertuis afirmaba que "sólo la costumbre disminuye lo maravilloso de la mayor parte de los misterios de la naturaleza", y agregaba que "estas fuerzas, que son absolutamente incomprensibles, parecen haber penetrado hasta en la Academia de ciencias [...] bajo el nombre de Rapports" [M. Maupertuis, Del orden verosímil del cosmos. Venus fisica, Alianza, Madrid, 1985, pp. 171-172]. 
que explique lo que tal fuerza ( $\mathrm{Kraft}$ ) es, sea ésta activa en uno o más seres. Lo que la filosofía hace es señalar, arreglar y clarificar luego de asumir tal fuerza, impulso y efecto desde el comienzo". ${ }^{41}$ En síntesis, a fin de pensar la historia, Herder trataba de poner juntas dos ideas en principio incompatibles entre sí: imaginaba las "fuerzas formadoras" de los vitalistas según el modelo de los gérmenes de Bonnet y los preformistas; algo que era, sin embargo, todavía inconcebible. La relación que entonces inicia con Lavater le aportaría, sin embargo, algunas de las líneas por las cuales comenzar a desanudar el enigma de las Kräfte.

Ya en Sobre el uso moderno de la mitología (1767), Herder planteaba, en el plano estético, el problema del Darstellung (la representación sensible de la idea). "La alegoria", decía, "representa conceptos abstractos en términos de los sentidos". ${ }^{42}$ La fisiognomía lo habilitaría ahora a ampliar tal concepto de la "alegoría" al conjunto de la naturaleza, convertido ya en el de "signo". El rasgo fisiognómico, en tanto que "signo", no es algo que represente nada anterior a él (como decía R. Klages del símbolo, "no es algo que está en lugar de otra cosa"), ${ }^{43}$ él mismo surge como el punto en que materia e idea se condensan. En el rasgo se encuentra cristalizada siempre una multiplicidad de afectos. Situado en la intersección de movimientos opuestos, aparece como la huella visible de su mismo proceso genético: él no es sino su propia historia. Esto abre la perspectiva a Herder para quebrar las dicotomías tradicionales de la Ilustración. El hecho de que aquel principio ordenador al que se buscaría penetrar no se instalase en el plano de la superficie visible del sistema de las analogías y las diferencias que se descubren en las formas vacías desplegadas en el espacio clasificatorio no necesariamente significaría que deba pensarse aquél como si ejerciera su influjo sobre los objetos desde más allá de los mismos. Éste podría ser objetivo, actuar en el mundo fenoménico, y, al mismo tiempo (como la fuerza gravitatoria, la electricidad y otras sustancias materiales-inmateriales), situarse por fuera del alcance de nuestros sentidos.

Esta definición no explicaba aún la naturaleza específica de aquellas fuerzas inherentes que mueven y moldean los fenómenos; pero, para entonces, el vitalismo comenzaba ya a abandonar sus connotaciones místicas: de la mano de Xavier Bichat (1771-1802) se convertía en una fisiología. Hacia los años 1780, Herder conoce las nuevas teorías vitalistas por un antecesor de Bichat, Albrecht von Haller (1708-1777), quien distinguió entre "irrita-

41 Herder, Sämtliche Werke, vol. VIII, p.178; citado por Clark, Herder. His Life and His Thought, p. 226.

42 Herder, Selected Early Works. 1764-1767, The University of Pennsylvania Press, University Park, Pennsylvania, 1992, p. 217.

43 Citado por Göde von Aesch, El romanticismo alemán, p. 250. 
bilidad", que sería la propiedad del cuerpo de contraerse ante un estímulo exterior, y "sensibilidad", por la cual las fibras del cuerpo humano conducen, tras el. contacto, la impresión subjetiva al alma. La primera sería una propiedad de los músculos; la segunda, de los nervios. De este modo, Haller demostraría la relación inmediata entre la irritabilidad y las fibras musculares, refutando la hipótesis de Stahl (vitalista conocido por su célebre teoría del "flogisto") de que la misma estuviera mediada por una excitación del alma. En Haller (cuya teoría Tissot la comparará con la de la gravitación, y pretenderá explicar con ella toda la economía animal), Herder encuentra un modelo de "fuerzas vitales" adheridas, como una propiedad, a los cuerpos. Basándose en este concepto, intentaría, según afirma en Vom Erkennen und Empfinden (1778), cerrar la brecha, aún presente en Leibniz, del dualismo entre alma y cuerpo, espíritu y materia: dado que ambos pueden reducirse a una misma Kraft, podrían así perfectamente interactuar.

Esto, a su vez, permitiria replantear el problema central pendiente de la década anterior, es decir, el de la génesis de un nuevo principio histórico (la fulguratio de Leibniz). Pero, para ello, debía reducir la pluralidad y especificidad de los vires o Kräfte de Haller a un único y común principio o Kraft. ${ }^{44}$ En Sobre el conocimiento del alma humana (1778), Herder comenzaba a hablar de una fibra sensitiva que, estimulada, podría considerarse como una primera manifestación de la vida. Y en un ensayo de 1785 , llamaba "chispa eléctrica" a la función generativa de la unión sexual. ${ }^{45}$ De todos modos, sólo una década más tarde, esta idea aparecería como confirmada empíricamente por Galvani, cuando lograse reactivar materia muerta mediante impulsos eléctricos ${ }^{46}$ [en este contexto fue que nació Frankenstein o "el nuevo Prometeo" (1800), de Mary Shelley]. La ciencia recién entonces

44 Por entonces, diversas hipótesis se ponen en boga. Jung-Stilling, junto con Mesmer, afirmaría la prioridad del magnetismo "El magnetismo animal", decía Jung-Stilling, "prueba irrefutablemente que poseemos un ser interior, un alma, que consiste en la chispa divina del espíritu eterno que posee voluntad y razón y en una envoltura de luz que es inseparable de él. Las materias luminosas, eléctrica, magnética y galvánica y del éter, todas parecen el mismísimo ser sometido a modificaciones diferentes" (citado por Göde von Aesch, El romanticismo alemán, p. 71).

45 Citado por Nisbet, Herder and the Philosophy, p. 146 (fuente no consignada). Se sabe, además, que Herder recibió tratamientos eléctricos (choques menores), según aconsejaban los galvanistas, a fin de restablecer el equilibrio interno de fuerzas.

46 Los'experimentos de Galvani con las patas crispadas de los sapos (1789) marcarían una cesura en la historia de las imágenes de la naturaleza. Ritter, cuyas conferencias señalan un hito en el desarrollo de la filosofía del romanticismo alemán, no dudaría ya de la posibilidad de reducir esas fuerzas ocultas a esencias físicas comprobables; aseguraba incluso que pronto habrian de fabricarse espejos que reflejaran la electricidad y el magnetismo [J.W. Ritter, Fragmente aus dem Nachlasse eines jungen Physikers (Heidelberg, 1810), vol. I, pp. 161-162; citado por Blumenberg, The Genesis, p. 621]. 
comenzaría a definir un nuevo programa para sí: si pretendía elevar al hombre a Dios, debía ser capaz no sólo de compartir con éste el don de la ubicuidad (como en Lambert), sino también de disputarle el monopolio de la capacidad creadora. Ideas para una filosofía de la historia de la humanidad (1784-1788), la opus magnum de Herder, anticiparía, en cierto modo, a aquélla en intentar adentrarse en tales terrenos hasta entonces inexplorados; pero, por eso mismo, en esta aventura se le plantearían una serie de problemas que no alcanzaría aún a resolver, ni podía todavía hacerlo.

\section{Evolución y escepticismo}

Ideas ha sido normalmente vista como señalando un regreso de Herder a la tradición Iluminista. ${ }^{47} \mathrm{Y}$, en efecto, el concepto epigenetista, al estilo de Buffon y Montesquieu no estará aquí ausente. Entonces Herder explicaría el origen de las diversas culturas en función de la influencia del medio: "La diversidad de las zonas y del aire", decía, "origina variedades en las plantas como en los animales y en los hombres". ${ }^{48}$ De todos modos, si bien no despreciará ahora las explicaciones físicas, entiende igualmente que éstas no agotarán nunca el objeto de la filosofía; "ninguna flor", insistía, "florece gracias al polvo externo que constituye el tosco elemento integrante de su estructura" (p. 139). Todo desarrollo vital supone aún, para él, la existencia de una "fuerza genética" interna sobre la cual las circunstancias externas actuasen; 49 "esta mutación tan trabajosa", aseguraba, "sólo pudo producirse de dentro hacia afuera" (p. 210). Pero, inversamente (y éste es su descubrimiento más reciente), esta fuerza interna sólo es efectiva en, y por medio de, la naturaleza: "El destino manifiesta sus intenciones por lo que acontece y por el modo en que acontece: por lo tanto, el intérprete de la historia desarrollará estas intenciones sólo a raíz de lo que existe de verdadero y se manifiesta en toda su extensión" (p. 439). No es pues necesario ya apelar a ninguna misteriosa qualitates occultæ: ${ }^{50}$ si existe un orden en el mundo, sólo en él se nos muestra, "Dios lo es todo en sus obras"

47 Meinecke (El historicismo y su génesis, passim) vulgariza este punto de vista.

48 Herder, Ideas para una filosofía de la historia de la humanidad, Losada, Buenos Aires, 1950, pp. 49-50. En adelante: la paginación en el texto corresponde a esta obra.

49 "La fuerza genética", decía, "es la madre de todas las formaciones sobre la tierra, cuya acción es fomentada o retardada por parte del clima mediànte un mero concurso causal" (Ideas, p. 206), "esa fuerza invisible no procede arbitrariamente, antes bien no hace más que manifestarse conforme a su naturaleza ințínseca" (Ideas, p. 207).

50 "Lo mismo cabe decir cuando me refiero a las fuerzas orgánicas de la creación; no creo que haya que considerar qualitates occultæ, pues a nuestra vista están sus efectos notorios, y no supe darles un nombre más determinado y puro. Sobre ellas y sobre alguna materia más, a las que sólo por alusiones hube de referirme, me reservo un tratamiento futuro" (Ideas, p. 14). 
(p. 13). Lo real deviene así en el signo manifiesto del principio invisible que le hace ser tal: "Toda forma externa de la naturaleza es reflejo de su interior" (p. 94). Un significante sin significado, o cuyo significado resulte inaccesible a nuestro entendimiento, es una contradicción, no es más que un amasijo sin sentido de caracteres informes.

El fracaso de Kant (con quien Herder inicia hacia esos años su polémica), deudor, para él, de las concepciones iluministas, radicaría en no haber logrado dar una respuesta satisfactoria a esta exigencia de síntesis entre causalismo y finalismo. Dado que para Kant las únicas explicaciones científicas serían las causales-mecanicistas, excluía toda consideración finalista del mundo fenoménico y lo situaba por fuera del ámbito de la razón. ${ }^{51}$ Así, simplemente lograría combinar las explicaciones causales y finales superponiéndolas, sin alcanzar una verdadera integración de ambas. De este modo, su fórmula mantiene el rígido dualismo entre unidad y diversidad, permanencia y cambio, ser y deber ser, razón y fe, libertad y necesidad. Herder, en cambio (y, con él, Schelling, Goethe y los románticos), apela a los ejemplos de la fisiología y la química como formas de conocimiento que estaban comenzando a definir nuevos ámbitos de saber bastante más allá de lo que Kant y los iluministas podían concebir, puesto que incluían ahora los procesos teleológicos entre los inherentes a los fenómenos. Esto provee un nuevo punto de partida para sus especulaciones sobre la idea de "Humanidad".

En Ideas, como ha sido frecuentemente señalado, el énfasis efectivamente se sitúa ya sobre aquella instancia unitaria que articularía el curso históricouniversal en una unidad de sentido. ${ }^{52}$ La pregunta por la "Humanidad" adquiere una renovada importancia desplazando a los "espíritus de los pueblos" como sujeto y soporte último de la inteligibilidad histórica. "En todos estos pueblos", afirma ahora, "se advierte un mismo principio activo, a saber, una misma razón universal que se empeña en producir la unidad de la multiplicidad, el orden del desorden, un conjunto simétrico y de belleza duradera de una gran variedad de fuerzas e intenciones" (p. 504). Ello, sin embargo, como vimos, lejos de representar un regreso a los postulados (mecanicistas) de la Ilustración, expresa un nuevo tipo de conciencia, de matriz "fisiognómica-fisiológica", sobre la unidad en los fenómenos de lo empírico y lo trascendente. ${ }^{53}$ Se trata ahora de buscar un concepto que pueda definir a la "Humanidad", entendida a la vez como el principio que

51 En su Crítica del juicio, Kant afirma que "puede ser pensada, sin contradicción, pero no ser concebida" [Espasa Calpe, Madrid, 1981, no. 64, p. 281].

52 "Hay que asombrarse", dice "ante la pluralidad de modificaciones que tienen lugar en nuestra tierra; pero más hay que asombrarse aun de la unidad a que sirve tan incomprensible diversidad" (Ideas, p. 94).

53 "Y si en lo que parezca lo más limitado y contrario", decía, "encontrara no sólo huellas de aquella gran fuerza formadora sino también concordancia notoria de lo ínfimo con el 
da vida (la oculta "fuerza genética") y el fin final hacia el cual tiende e! género humano (la Razón y la Libertad).$^{54}$ De todos modos, es cierto que ello plantea aún el problema de cómo evitar una recaída en una visión lineal de la historia. De hecho, los diversos principios históricos no presentarán ya esa completa alteridad con que Herder nos los mostrara apenas diez años antes: los ciclos y las revoluciones en la historia se instalan ahora en el nivel de la textura visible de la historia, anudada una y otra vez por la trama continua oculta que la ordena: toda "decadencia [en ella es] aparente, un cambio de figuras y formas. Pero ese cambio jamás afecta lo interno de la naturaleza, la cual supera toda ruina" (p. 508). La recomposición de la unidad del principio oculto del desarrollo histórico parece, pues, sólo posible de lograrse en detrimento de la especificidad de sus formas y figuras exteriores. El cambio en la historia se convertiría, así, en una mera apariencia.

Éste, sin embargo, no es el concepto al que Herder aspiraba. En definitiva, Ideas expresaría la exigencia sentida de una nueva síntesis sostenida sobre el principio de la existencia de una finalidad inmanente en la historia (y ya no trascendente a la misma, como apareciera en Filosofía de la historia) que se desplegaría en infinidad de formas diversas, síntesis a la que Herder, sin embargo, aún entonces no alcanzaba a plasmar completamente. Pero para comprender el tipo de tensiones que efectivamente surgen en su pensamiento en la realización de un proyecto tal, no basta con apelar a la idea de un rechazo instintivo suyo a cualquier empresa racional. En realidad, esas tensiones resultan de su acercamiento a ésta. Conviene, pues, situar su filosofía "madura" de la historia en el contexto de los debates de la época y la naturaleza problemática de las categorías a las que entonces apela.

Dentro de aquellos modos fragmentarios de aproximación a los fenómenos histórico-sociales a los que Herder critica, incluye la filosofía goethiana. El concepto de Urform ("protoforma") que Goethe elabora luego de su viaje a Sicilia, le hacía posible pensar un curso histórico y natural unitario y, a la vez, infinitamente plástico. Lá idea de Urform llevaba a hacer anclar en los orígenes el principio unitario que confiere tal unidad y hace inteligible

designio del Creador pasando hacia lo inconmensurable, será la más bella cualidad de mi razón imitadora de Dios que siguiera este plan y me acomodara a la razón celestial" (Ideas, p. 18). Éste será uno de los temas preferidos de Goethe. En Fausto decía: "Todo lo efímero / símbolo es sólo / iEs aquí un hecho / lo inasequible! / iAquí se cumple / lo indescriptible!" [Goethe, Obras literarias, Aguilar, Madrid, 1944, vol. II, p. 646], y en el Diván de Occidente y Oriente pedía: "En cada lamparilla, de discreto fulgor, / debéis ver el reflejo de la luz eternal" (ibid., vol. I, p. 1105).

54 "Mi deseo es reunir en la palabra Humanidad todo cuanto he dicho hasta aquí sobre la noble formación del hombre para la Razón y la Libertad" (Ideas, p. 118). En las conclusiones habla, en cambio, de la Razón y la Justicia. La idea de Justicia se ajustaba mejor al concepto fisiológico de adecuación de un órgano a su función. 
todo desarrollo ulterior (resultado de sucesivas "metamorfosis" a partir de aquel tipo originario). Pero, de este modo, Goethe dejaba indeterminado el sentido de tales transformaciones. ${ }^{55}$ No había una finalidad perceptible en ellas. Para Herder, en cambio, como vimos, lo que ordenaba el transcurso histórico se situaba en el horizonte común hacia el cual todos los pueblos tenderían a converger (la humanidad) antes que en su punto de partida. ${ }^{56}$

En Goethe, como en Kant, el rechazo a todo finalismo derivaba de la idea, de raíz iluminista, de que los procesos naturales responderían a mecanismos puramente causales, y que sólo éstos serían objeto legítimo de conocimiento. La idea de "causa final" supondría la remisión a un intelecto superior (intellectus archetypus al que le estaría dada una intuición sensible del todo). ${ }^{57}$ Sin embargo, la idea de Urform hacía posible (y con ello Goethe creía haber superado las limitaciones del criticismo kantiano) a nuestro intelecto ectípico (discursivo) convertirse al menos en una suerte de remedo de intellectus archetypus sin por ello salirse del plano fenoménico: éste podría también partir de una intuición inmediata de las formas originarias (Urforms), para llegar luego a las derivadas y, así, reconstruir el proceso genético de la naturaleza toda siguiendo leyes exclusivamente mecánicas. Y ello resultaría en su peculiar concepción evolucionista (compartida luego con Geoffroy de Saint-Hilaire) de la naturaleza viviente que se autoproduce por una serie sucesiva de metamorfosis, ocurridas por la presión ejercida por agentes físicos sobre una masa orgánica (suerte de "plasma vegetativo", según lo definiría más tarde Weismann) lo suficientemente plástica como para transmutarse en infinidad de formas diversas ante la acción de fuerzas exteriores. Esto, en verdad, no excluía en Goethe (como tampoco lo hacía Geoffroy) un componente vitalista (las llamadas "simpatías naturales"), pero en él (a diferencia de Herder) éstas llevaban a reducir los procesos biológicos internos de los organismos a un papel esencialmente pasivo.

Si bien este concepto genético de la vida resultaba para Herder también adecuado en el nivel filogenético ${ }^{58}$ (de allí que algunos hayan visto en él,

55 "En la investigación de la Naturaleza, no menos que en lo moral, de un imperativo categórico; téngase en cuenta solamente que ello no está al final, sino en los comienzos" (Goethe, "Máximas y reflexiones", en Obras literarias, vol. II, p. 2230).

56 Tampoco Goethe negaría (especialmente luego de la batalla de Jena, 1807, que marca cierto giro espiritualista en su pensamiento), en el plano histórico, la idea de una finalidad; aunque afirmaba que la misma sería incognoscible. "Tan limitada es de suyo la humanidad", decía, "que no tiene ninguna idea ni del principio ni del final de su existencia" (Goethe, "Diván de Occidente y Oriente", en Obras literarias, vol. I, p. 1305).

57 Kant, Crítica del juicio, no. 77, pp. 321-323.

58 "La naturaleza, en la infinita variedad en que se complace, parece haber formado todo lo vivo de nuestra tierra de acuerdo con un plasma de organización principal [...] Se desprende, por lo tanto, que como esta forma principal tiene que variar siempre según los géneros, 
equivocadamente, a un precursor de Darwin), ${ }^{59}$ es decir, para explicar la "escala del ser", esto, precisamente, excluía para Herder todo concepto propiamente transformista. En la medida en que dicho "plasma vegetativo" era, también para él, esencialmente pasivo, no podría éste operar mutaciones genéticas; y sería absurdo, aseguraba, pensar que ellas pudieran producirse por la mera acción del medio. En este nivel filogenético, pues, el concepto de desarrollo sólo podía entenderse como refiriendo a un despliegue puramente "lógico" (según la definición preformista clásica; i.e., como una jerarquía en la escala del ser) y no propiamente "histórico". Y, en efecto, para él era contraria a toda evidencia empírica la idea de que de una especie natural pudiera surgir otra distinta de ella. ${ }^{60}$ En este sentido, su pensamiento resulta, para muchos de sus críticos actuales, más conservador que el de Goethe. Sin embargo, según vimos, este fijismo venía determinado, paradójicamente, por una concepción mucho más dinámica en cuanto a la naturaleza de los procesos vitales (que es, en definitiva, de donde surgirá realmente el evolucionismo del siglo pasado).

En efecto, según lo ya expuesto, para Herder, todo cambio o metamorfosis sólo puede provenir de un impulso interno, una "fuerza genética" activa. El concurso de un agente externo sólo podría desencadenar procesos cuya evolución depende de un plan de desarrollo inherententemente determinado ("esta mutación tan trabajosa sólo pudo producirse de dentro hacia afuera [...] no se diga que algún artificio, $o$ acaso el sol, hayan achatado la nariz del negro") (p. 210). Ahora bien, y ésta es la paradoja, es por su mismo carácter activo que estos principios vitales no podían aún concebirse como informando, siguiendo exclusivamente sus mismas tendencias internas de desarrollo, especies diversas, lo que supone siempre la participación de principios de desarrollo cualitativamente distintos entre sí. En fin, esta idea de preformismo biológico, trasladado al terreno de la historia, plantearía, nuevamente, la misma serie de problemas que llevara a Herder diez años antes a plantear la hipótesis de una intervención providencial en el mo-

especies, destinaciones y elementos, un ejemplar explica a otro. Lo que en tal criatura esbozo la naturaleza como obra accesoria, lo ejecutó en otra, por decirlo así, como obra principal" (Herder, Ideas, p. 57).

59 Friedrich von Bärenbach, Herder als Vorgänger Darwins und der modernen Naturphilosophie. Beiträge zur Geschichte der Entwickelungslehre im XVIII. Jahrhundert (Berlín, 1877).

60 "Ninguna criatura que conozcamos", aclaraba Herder, "se salió de los orígenes de su organización para prepararse otra contraria" (Herder, Ideas, p. 90), "toda criatura sólo puede y debe ser organizada por criaturas de su especie" (ibid., p. 138). Ese "plasma de organización principal" de que habla no es exactamente el "plasma germinativo" de Weismann (a pesar de la coincidencia, nada casual, de nombres). Más bien, cabe interpretarlo como una suerte de reformulación de la idea bíblica del "barro". 
mento de la emergencia de un nuevo principio histórico (pues lo contrario hubiera llevado, otra vez, al monismo).

Llegado a este punto, sólo cabían dos opciones. Si la meta común de los diversos pueblos y épocas, que es la humanidad, estuviera ya contenida también en su punto de partida (como parece sugerirlo), el curso histórico se tornaría así en algo absolutamente lineal y determinista (tendencia hacia la cual parece inclinarse cuando dice que "de ahí que la marcha hacia ésta [la Humanidad] fuera tan uniforme a pesar de todas las diferencias de formas") (p. 115). Pero, entonces, esto hace de sus circunstancias meros accidentes que no alteran su transcurso ni representan modificaciones de orden cualitativo en el nivel de su conformaciones. La peculiaridad de los "espíritus de los pueblos" se diluiría en el ancho curso unitario de la Humanidad. Pero esta solución no la podía Herder aceptar completamente: "En todas partes", insistía, "se ve destrucción y muerte sin que lo nuevo aventaje a lo destruido, las naciones florecen y se marchitan; en las marchitas no vuelven a florecer otras flores más hermosas. Las culturas se trasladan, mas no por esto se perfeccionan" (p. 488). La otra posibilidad podría haber sido sencillamente invertir el esquema goethiano (a fin de salvar la noción de "causas finales"), haciendo cerrar la lógica histórica exclusivamente en el momento hacia el cual todas sus formaciones particulares tienden a converger (la Humanidad), dejando indeterminados lo puntos de partida respectivos (a fin de salvar la especificidad de sus desarrollos). Pero entonces, dado que la lógica de la preformación se vería quebrada, tal convergencia sólo podría explicarse, nuevamente, por la acción permanente de un entendimiento superior que la fuera orientando en su desarrollo hacia esa meta prefijada. En definitiva, lo que resurge aquí es el problema, en apariencia insoluble, pero a la vez ineliminable, de las fulguratio leibnicianas; sólo que Herder ahora alcanza a percibir más claramente que dicho problema resulta tal, debido, no a una contradicción intrínseca al concepto evolucionista, sino a las limitaciones inherentes al sistema de pensamiento del preformismo biológico.

Tampoco puede servirnos aquí de guía la llamada filosofía de los gérmenes de Bonnet, puesto que en parte no está demostrada la intención del paso a una nueva existencia, y en parte no le corresponde. Nadie descubrió en nuestro cerebro un cerebro espiritual, germen de una nueva existencia (p. 127).

Pero tampoco encontraba disponible un modelo alternativo; en definitiva, tampoco él, pensaba, podría escapar a las limitaciones de su tiempo. Incapaz de cortar este nudo gordiano, Herder parecería volver entonces sencillamente a una versión aggiornada del escrito del 1774: "En la historia de nuestro linaje", insistía, "muchos pasos y éxitos resultan incomprensibles 
sin una intervención superior" (p. 151). Tan sólo quedaría confiar, pues, en que Dios, "con su infinita mano de artista hará florecer nuestros capullos de humanidad" (p. 147). Sin embargo, esto contradecía todos sus postulados actuales de corte ya cerradamente naturalista. "Toda la historia del género humano", aseguraba, "no es más que una pura historia natural de fuerzas, acciones e instintos humanos en función del lugar y el tiempo" (p. 438). La filosofía "madura" de Herder parece abandonar, pues, la idea de la irreductibilidad de la acción de Dios en el mundo al conocimiento humano, sólo para terminar desgarrada entre una doble antinomia (entre lo particular y lo general, por un lado; y entre lo natural y lo sobrenatural, por otro). En realidad, lo que se observa aquí es una tensión entre la primera (escrita en 1784, inmediatamente después de su arribo a Weimar) y el resto de las partes de esta obra (cuya publicación se despliega a lo largo de cuatro años en los que Herder realiza su estudios más sistemáticos de las nuevas corrientes científicas antes analizadas). ${ }^{61}$ Sin embargo, conviene no exagerar esta tensión. La primera deriva de este "giro naturalista" en todo el pensamiento finisecular dieciochesco debía ser un escepticismo (que atraviesa por igual toda esta obra de Herder) respecto de la posibilidad de acceder a la naturaleza de tales fuerzas genéticas a las que aquí apelaba (y que, como vimos, sólo cobran credibilidad empírica con Galvani, luego de que Herder completara la publicación de esta obra): "no tenemos sentidos para eso" (p. 138), concluiría éste. Atrapado en la intersección de senderos cuya trayectoria sólo posteriormente habría de aclararse, ninguno de los cuales vislumbra transitables, la filosofía de Herder terminaría por abandonarse a cierto escepticismo epistemológico.

Su pesimismo antropológico ("durante toda la vida dominará el animal en el hombre", decía) (p. 150), de matriz pietista ayuda, en parte, a explicar este giro escéptico. En definitiva, no creía que su propia época de Ilustración revelase ningún progreso cierto; "no es sólo", decía, "por razones de fanatismo religioso si el europeo en muchos países del Islam es llamado animal impuro" (p. 223) (visión en la que se trasluce cierto desdén aristocrático hacia las transformaciones de su tiempo). No obstante, lo que allí se expresa involucra sólo en parte cuestiones de índole ideológica; como vimos, en

61 Tales contradicciones pueden observarse al contrastar las dos citas siguientes. Mientras que en la primera parte afirma que "así, pues, la historia de la humanidad se convierte, al fin y al cabo, en un teatro de transformaciones cuya visión completa posee solamente Aquel que inspira todas esas formas y se complace en su variedad. Él edifica y destruye, retoca las figuras y las modifica cambiando el mundo que las rodea" (Ideas, p. 192), más adelante aseguraría, en cambio, que "en la naturaleza física no contamos nunca con un milagro: observamos las leyes cuya causalidad hallamos siempre efectiva, inmutable y regular. Siendo así, ¿el reino de la vida humana, con sus campos de fuerzas, cambios y pasiones habría de escapar a esta serie de leyes naturales?" (Ibid., p. 438). 
este escepticismo herderiano operan también razones estrictamente epistemológicas relativas al curso de la historia de las ciencias de su tiempo. Y lo cierto aquí es que en esta obra se descubre cierta conciencia respecto de que su proyecto intelectual no encontraba aún en ellas el marco propicio para su florecimiento. "Mi obra revela", decía, "que todavía no puede escribirse una filosofía de la historia humana, pero que tal vez pueda escribirse a fines de este siglo o de este milenio" (p. 14). El estancamiento relativo de las ciencias biológicas, en particular, aparece, para él, en gran medida como responsable de ello.

Buffon es sólo el Descartes de esa modalidad, llamado a ser pronto refutado y superado por Kepler y Newton a base de hechos coincidentes [...] Sería hermoso que con ellos muchas fuerzas naturales tenidas ahora por qualitates occultæ pudieran reducirse a esencias demostradas (p. 24).

Lo que se trasluce allí, evidentemente, es cierto malestar epistémico, que anunciaba la inminencia de un vuelco decisivo en este campo; aunque habría que esperar el estallido de la Gran Revolución para que se produjera.

\section{El problema magnético}

La Revolución Francesa (a la que Herder se adhiere en tanto que ve en ella una reacción contra las monarquías ilustradas al estilo de Federico II, por quien nunca sintió demasiadas simpatías) no sólo remueve, al menos en parte, su pesimismo, sino que también, algo más relevante para lo que aquí nos ocupa, abre las puertas a la aparición de nuevas disciplinas científicas (galvanismo, magnetismo animal, química, embriología). Y éstas ofrecerían a Herder, finalmente, un modelo de "forma" histórica, distinto del de la cicloidea lambertiana: el péndulo. Entonces inicia su proyecto de fundación de un periódico (1800-1804) cuyo título, Adrastea (nombre de la diosa griega Némesis dispensadora de felicidad y vengadora del mal, la diosa del "destino"), expresa este nuevo concepto histórico. El movimiento pendular (un proceso no menos ciego que la guía providencial de 1774) tiene, como los espíritus de los pueblos, su centro propio hacia el cual gravita, "toda perfección de una cosa", dice en Dios. Algunas Conversaciones, "es su realidad", 62 contiene dentro de sí (como la mónada) su propia idea. Pero este centro ya no es el núcleo generador desde donde todo irradia, sino la resultante de la interacción de fuerzas encontradas, el juste milieu. La gota sirve de ejemplo de ello.

62 Herder, Sämtliche Werke, vol. XVI, p. 552; citado por Brown, The Shape, p. 30. 
La gota es una esfera. En una esfera todas las partes rodean homogéneamente su punto central en orden y armonía. La esfera descansa sobre sí; su centro de gravedad está en medio. Su forma es así el estado más bello de persistencia de entidades homogéneas que entran en contacto alrededor de su punto medio y se contrabalancean con igual fuerza. Así, un mundo viene a la existencia en la gota de acuerdo con las leyes necesarias de armonía y orden. ${ }^{63}$

Análogamente, el movimiento pendular puede verse como el arco abarcado por el desplazamiento de un objeto tensionado entre dos polos situados en los extremos del diámetro del semicírculo que dibuja su trayectoria. El juego de las polaridades que gobierna el universo entero define también la dinámica particular de cada cuerpo. "Tienes en el magneto", decía, "la imagen de lo que son el amor y el odio en la naturaleza, y estoy seguro de que cosas idénticas se encontrarán en muchos, quizás en todos, los fluidos". ${ }^{64}$ Del mismo modo, "la vida" podría ahora, finalmente, explicarse como el incesante movimiento generado desde dentro de los fenómenos mismos por "la actividad de una fuerza interior" ${ }^{65}$ Lo que aquí resulta complicado, sin embargo, es comprender cómo puede surgir, de este modelo, cierta idea de progreso; "ise puede concebir", se pregunta, "una fuerza continuamente operativa sin continua operación, es decir, un avance sin avance?”, ¿no es ello una contradicción? A lo que responde:

iY lo es! Cada fuerza que hace su aparición en el tiempo y en el espacio debe mantenerse dentro de los límites de su tiempo y lugar dados. Pero cada actividad hace la actividad subsecuente más fácil [...] Ninguna de estas operaciones puede ser en vano. Debe haber progreso, avance en el reino de Dios, dado que no puede haber quietud, y menos regreso. ${ }^{66}$

Quizás una mejor imagen (o "forma", en el sentido de Brown) para explicar esta idea sea la de un péndulo que se desplaza sobre su eje vertical (probablemente, a "saltos", al comienzo de cada nueva revolución). Esta "forma", aunque no planteada por Herder mismo, nos puede servir al menos para ejemplificar las razones de la nueva importancia que adquiere en Herder el juste milieu: en el momento en que la trayectoria de un pueblo coincide con el plano del eje vertical del péndulo, éste alcanzaría no sólo su forma más acabada, sino que se situaría también en aquella perspectiva desde la cual podría accederse a una visión de la trayectoria completa seguida por el curso histórico-universal. Al menos temporalmente, su centro

63 Herder, Dios; en Wilshire, Romanticism, pp. 62-63.

64 Herder, Dios, p. 64.

65 Ibid., p. 170.

66 Ibid., pp. 70-71. 
particular coincidiría con aquel centro absoluto que buscaba Lambert en el universo. Esta idea herderiana de la coincidencia pendular remite, en realidad, a otra también postulada por Lambert. Éste planteó, a modo de hipótesis, la posibilidad (cierta, pero altamente improbable de que ocurra en el curso de la historia humana) de que alguna vez en millones de años todos los planetas y estrellas se sitúen en un mismo plano y así se nos revele la armonía de la estructura del cosmos observándolo desde cualquiera de sus infinitos puntos (es decir, incluso viéndolo desde nuestra excéntrica perspectiva). ${ }^{67}$

El juste milieu es, pues, donde coinciden la felicidad particular y la absoluta; "los extremos y las oscilaciones", decía ya en las conclusiones de Ideas, "terminan finalmente en el movimiento regular del bienestar permanente cuya virtud está en el justo medio" (p. 513). Sin embargo, éste encierra también siempre, al menos en el contexto del pensamiento de la época, la idea de una pérdida así como la de una desviación del curso natural. "Géneros y pueblos", decía, "ensayan actitudes extremas opuestas, hasta que el conjunto llega al centro de reposo, como lo hace el péndulo". En un sentido, la metáfora del péndulo supone cierto regreso al mismo concepto que llevó a Kepler a descubrir la trayectoria elíptica de los planetas: las oscilaciones resultarían de la radical imperfección humana, no conllevarían ninguna condición necesaria al desarrollo lógico de la historia, la humanidad no gana nada en cada una de ellas más que sufrimientos.

Herder encuentra, pues, finalmente, una solución al problema que lo preocupa desde sus obras tempranas (el de la relación de lo particular y lo general), pero sólo al precio de moderar el radicalismo de su historicismo juvenil. Sin embargo, esto se debería más a las limitaciones de las ciencias naturales de su tiempo que al resurgimiento de un persistente racionalismo (iluminismo) suyo al que su veta espiritualista no terminaba de controlar y abatir. Herder representaría así uno de esos casos, sumamente excepcionales en la historia del pensamiento, en que comienzan a definirse categorías que señalan un horizonte de preguntas al que aquellas mismas categorías no pueden aún responder. De hecho, cuanto más se familiarizaba con las ciencias de su tiempo, más se alejaba Herder del Iluminismo, aunque no por ello anticipaba tampoco, de forma aún incompleta, un supuesto modelo "eterno" de cientificidad que luego se encarnaría en Darwin. En verdad, la síntesis a la que todo el pensamiento de Herder se orientaba, sin alcanzarla, se produciría sólo unos pocos años más tarde, cuando el concepto preformista en la biología se redefine de tal modo que incorpora un elemento dinámico (algo que, hasta entonces, aparecía como una contradicción en los términos). Tal desarrollo provendría, esta vez, del terreno de la embriología.

${ }^{67}$ Lambert, Cosmological Letters, en Munitz; Theories of the Universe, p. 252. 
Hacia 1812, J.F. Meckel (1781-1833) reactualiza la teoría propuesta por Wolff en su Theoria Generationis (1759) y que permaneciera largamente olvidada. Wolff había descubierto que, contra lo que afirmaban las teorías del preformismo germinal, en el desarrollo del embrión surgen partes y órganos que no se encontraban presentes previamente. La pregunta que se planteaba entonces (y que llevó a descartar la teoría wolffiana) era la de cómo explicar que todos aquellos órganos diversos correspondieñtes a un mismo ser pudieran mantenerse siempre perfectamente correlacionados, siendo resultado de una serie de transformaciones operadas sobre una sustancia originariamente inorganizada. Wolff apelaba entonces a la hipótesis de un vis essentialis (fuerza vital). En Historia de la evolución de los animales (1828), K.E. von Baer (siguiendo las ideas de Meckel) da finalmente forma a la primera teoría embriológico-evolutiva moderna. En ella reinterpreta el desarrollo embrional como el pasaje sucesivo a través de diferentes formas, siendo que las primeras reproducirían sólo los rasgos esenciales que identifican su clase, luego los del orden respectivo, hasta que aparecen los de su especie particular y, finalmente, sus características peculiares como individuo. La embriología formulaba al fin el modelo de un sistema de formación progresiva en el que lo que se encuentra preformado no es ningún conjunto de rasgos definidos, sino el principio que los conforma. Este principio sería cierto orden lógico de transformaciones sucesivas (algo parecido a lo que hoy llamamos un "programa genético").

Podemos decir que el concepto embriológico de von Baer forma parte de un sistema de saber al que Herder sirve de preámbulo (distintos autores incluso han considerado a Herder un precursor de Kielmeyer y von Baer). ${ }^{68}$ Éste, por otra parte, presenta, como vimos, cierta continuidad con conceptos típicamente tardío-iluministas; existe, como decía Meinecke, cierta "dialéctica interna" que lleva de uno a otro. Sin embargo, aquél ni surge linealmente de éstos, ni se proyecta del mismo modo sobre los sistemas de pensamiento que lo suceden, v.g., el darwinismo, como si fuera una mera forma inacabada de los mismos. Y ello porque la problemática específica 'sobre la que se instala la filosofía de la historia de Herder sólo surge precisamente del cuestionamiento de modelos que para la Ilustración aparecían como inopinables (así como el tipo de respuestas que luego surgirían de aquellas preguntas que atormentaron a Herder sólo se abrieron a partir de

68 "La influencia de Herder sobre Kielmeyer es tan obvia que no ha escapado ni a los historiadores modernos, ni a los contemporáneos de Herder [...] Según E. Jacobshagen, Ideas de Herder es el punto de partida de todo el movimiento biológico iniciado alrededor de 1800 , incluyendó no sólo a Kielmeyer, sino también a Goethe, Cuvier y Pfaff" [O. Temkin, "German Concepts of Ontogeny and History around 1800", The Double Face of Janus and Other Essays in the History of Medicine, The John Hopkins University Press, Baltimore y Londres, 1977, pp. 384-385]. 
la redefinición de algunos de sus conceptos de base, como las ideas particulares de "evolución" y "organismo" en las que su filosofía se sostenía). Esto señalaría el paso de la historia a la Historia (en el sentido definido por Foucault, una historicidad que les viene a los objetos desde dentro), pero, para llegar a la idea de la misma, habría que esperar una serie de redefiniciones que, como vimos, sólo tras su muerte se producirían. Y tampoco vendrían por el lado en que él las buscó. El "giro naturalista" de Herder estaba aún determinado por un sustrato de matriz vitalista tardío-iluminista que lo llevaba a concebir la fuente última de vida o Kraft (aquélla a cuyo descubrirniento se orientaría todo su "método genético") en términos de alguna suerte de Sustancia (como la electricidad, el magnetismo, etc.). La concepción de una Historia conllevaría, en cambio, hacer del género humano un Sujeto (no la causa externa y anterior a sus atributos, sino - como los gérmenes de Baer- el propio principio del movimiento de ponerse fuera de sí permaneciendo a la vez él mismo - i.e., un "programa genético"-)..$^{69}$

En síntesis, si la figura de Herder sirve de símbolo alguno, sólo puede serlo del malestar epistémico producido por la combinación de desarrollos desiguales en las ciencias de su tiempo (algo de lo que Herder era, por otra parte, en gran medida consciente, sin por ello poder aceptarlo en su totalidad). Si efectivamente existen tensiones en su filosofía, no se deben tanto a la lucha de antinomias cuasi eternas (como racionalismo y espiritualismo) como al hecho de que la misma se vería permanentemente empujada, dentro de la economía de su propio sistema y debido a la acción de estos desarrollos desiguales, a confrontar lo que constituían sus propios límites, aquello que, dentro de su horizonte particular de pensamiento resultaba a la vez necesario y, sin embargo, "impensable": la idea de un orden del mundo que sólo se fuera constituyendo progresivamente siguiendo sólo sus propias tendencias inmanentes de desarrollo.

69 Éstas se expresan ya en Cartas sobre la educación estética del hombre (Aguilar, Madrid, 1963), de Schiller. La distancia que lo separa de Herder (y, especialmente, de su concepto de "pendularidad") fue perfectamente definida por éste en el contraste que establece entre las antinomias del pensamiento anterior (i.e., Formtrieb, o impulso formal versus Stofftrieb, o impulso sensible) y la nueva sintesis que encuentra la expresa en el concepto de Spieltrieb, - "espíritu de juego". Lovejoy descubre connotaciones místicas tras "este confuso esfuerzo de Schiller por conciliar lo inconciliable" (The Great Chain, p. 303). Habermas, en cambio, ve en él anticipada su propia idea de "racionalidad comunicativa" [El discurso filosófico de la modernidad, Taurus, Buenos Aires, 1989, cap. II]. 